\title{
Comparative study on the use of specific and heterologous microsatellite primers in the stingless bees Melipona rufiventris and $M$. mondury (Hymenoptera, Apidae)
}

\author{
Denilce Meneses Lopes, Lúcio Antônio de Oliveira Campos, Tânia Maria Fernandes Salomão \\ and Mara Garcia Tavares \\ Departamento de Biologia Geral, Universidade Federal de Viçosa, Viçosa, MG, Brazil.
}

\begin{abstract}
Due to their high degree of polymorphism, microsatellites are considered useful tools for studying population genetics. Nevertheless, studies of genetic diversity in stingless bees by means of these primers have revealed a low level of polymorphism, possibly the consequence of the heterologous primers used, since in most cases these were not specifically designed for the species under consideration. Herein we compared the number of polymorphic loci and alleles per locus, as well as observed heterozygosity in Melipona rufiventris and M. mondury populations, using specific and heterologous primers. The use of specific primers placed in evidence the greater frequency of polymorphic loci and alleles per locus, besides an expressive increase in observed heterozygosity in $M$. rufiventris and $M$. mondury, thereby reinforcing the idea that populational studies should be undertaken by preferably using species-specific microsatellite primers.
\end{abstract}

Key words: Melipona, stingless bees, microsatellite, transferability.

Received: February 26, 2009; Accepted: October 14, 2009.

\section{Introduction}

Microsatellites or simple sequence repeats (SSR) are regions of the genome made up of short repeat sequences, consisting of one to six nucleotides (Hancock, 1999). Microsatellites have been widely used in studies with various organisms, due to their high degree of polymorphism and co-dominance. One of the limiting stages in the use of these markers is the development of specific primers. However, it has been discovered that the regions flanking microsatellites are very much conserved, and thus primers can be used among species, even among those from different genera (Ferreira and Grattapaglia, 1998). Consequently, the use of heterologous primers has been reported in several studies on bees (Carvalho-Zilse and Kerr, 2006; Francisco et al., 2006; Insuan et al., 2007).

Nevertheless, it is known that by using heterologous primers, the level of information differs among species, generally with a decrease in successful amplification as the genetic distance increases among species (Francisco et al., 2006), thereby inducing a reduction in observed polymorphism. But to what degree does this loss of information lead to mistaken conclusions regarding population genetic structure?

Send correspondence to Mara Garcia Tavares. Departamento de Biologia Geral, Universidade Federal de Viçosa, 36570-000 Viçosa, MG, Brazil. E-mail: mtavares@ufv.br.
In bees, microsatellite primers were first described for Apis mellifera and Bombus terrestris (Estoup et al., 1993), and currently there are reports on primers for four stingless bee species: Melipona bicolor (Peters et al., 1998), Scaptotrigona postica (Paxton et al., 1999), Trigona carbonaria (Green et al., 2001) and M. rufiventris (Lopes et al., 2009).

Tavares et al. (2007) used M. bicolor microsatellite primers when assessing genetic diversity in M. mondury and $M$. rufiventris populations. They analyzed samples from forest and savanna regions in the state of Minas Gerais, thereby uncovering low genetic diversity in these species, when compared to that found in species analyzed with the use of species-specific primers. However, it is not known whether these estimates were the outcome of using heterologous primers, seeing that some authors reported the presence of null alleles in a like situation (Pépin et al., 1995), or due to the small size of the populations examined (Campos, 1998), with the consequential reduction in genetic diversity.

The objective of the present study was to analyze populations of $M$. mondury and $M$. rufiventris with recently designed specific microsatellite primers (Lopes, 2008) and compare data with those obtained when primers developed for $M$. bicolor were used. 


\section{Material and Methods}

\section{Biological material}

Melipona mondury and M. rufiventris workers, collected in the state of Minas Gerais, were analyzed (Table 1). Total DNA was extracted, according to the protocol recommended by Waldschmidt et al. (1997), by using the adult worker thorax of one bee per colony.

\section{Molecular analysis}

The bees were analyzed using nine primers specific for M. mondury (Mmo08, Mmo10, Mmo11, Mmo15, Mmo19, Mmo20, Mmo21, Mmo22 and Mmo24) (Lopes, 2008), nine primers specific for M. rufiventris (Mru03, Mru04, Mru05, Mru06, Mru09, Mru10, Mru11, Mru12 and Mru14) (Lopes et al., 2009) and nine heterologous primers designed for M. bicolor (Mbi32, Mbi215, Mbi218, Mbi232, Mbi233, Mbi254, Mbi256, Mbi259 and Mbi278) (Peters et al.,1998).

PCR amplifications were carried out in reactions of $10 \mu \mathrm{L}$ containing $12.5 \mathrm{ng}$ of genomic DNA, 1X Promega Taq PCR buffer, 0.5 or $0.25 \mu \mathrm{M}$ of each forward and reverse primer, $0.1 \mathrm{mM} \mathrm{dNTP,} 1.5$ or $1.0 \mathrm{mM} \mathrm{MgCl}_{2}$, and $1 \mathrm{U}$ Taq DNA polimerase (Promega). The conditions for the PCR were the following: $94^{\circ} \mathrm{C}(3 \mathrm{~min})$ followed by $40 \mathrm{cy}$ cles at $92{ }^{\circ} \mathrm{C}(30 \mathrm{~s})$, specific pairing temperature for each primer $(1 \mathrm{~min})$ and $72^{\circ} \mathrm{C}(30 \mathrm{~s})$ and a final extension step at $72{ }^{\circ} \mathrm{C}(5 \mathrm{~min})$. The $\mathrm{PCR}$ products were resolved in $8 \%$ denaturing polyacrylamide gel and visualized by staining with $0.2 \%$ silver nitrate.

Table 1 - Locality and number of the colonies of Melipona rufiventris and M. mondury analyzed.

\begin{tabular}{llc}
\hline Species & Locality & Number of colonies \\
\hline & Guimarânia & 9 \\
& Patos de Minas & 4 \\
& Patrocínio & 2 \\
& Arcos & 2 \\
M. rufiventris & Uberaba & 2 \\
& Córrego Danta & 3 \\
& Pequi & 1 \\
& Formiga & 2 \\
\hline & Total & 25 \\
\hline Coluna & 1 \\
& Itamarandiba & 3 \\
& Resende Costa & 6 \\
& Rio Vermelho & 5 \\
& Pote & 4 \\
& Diogo Vasconcelos & 3 \\
& Marliéria & 1 \\
\hline & Total & 23 \\
\hline
\end{tabular}

The polymorphism level was determined by the number of polymorphic loci $(\mathrm{P})$, the mean number of alleles per locus (A) and observed heterozygosity $\left(\mathrm{H}_{\mathrm{o}}\right)$. All these analyses were carried out using the PopGene version 1.32 (Yeh et al., 1999) and TFPGA (Miller, 1997) programs.

\section{Results and Discussion}

The number of polymorphic loci and alleles per locus, as well as heterozygosity in M. rufiventris and M. mondury, when specific and heterologous primers were used, respectively, appears in Tables 2 and 3.

On comparing the two Tables, it can be seen that all the nine primers designed specifically for these two species, except for one in M. mondury, were polymorphic in

Table 2 - Diversity parameters for nine microsatellite primers designed specifically for Melipona rufiventris and M. mondury.

\begin{tabular}{cccccccccc}
\hline \multicolumn{3}{c}{ M. rufiventris } & & & \multicolumn{3}{c}{ M. mondury } \\
\cline { 1 - 1 } Locus & $\mathrm{A}$ & $\mathrm{H}_{\mathrm{o}}$ & $\mathrm{H}_{\mathrm{e}}$ & & Locus & $\mathrm{A}$ & $\mathrm{H}_{\mathrm{o}}$ & $\mathrm{H}_{\mathrm{e}}$ \\
\hline Mru03 & 3 & 0.43 & 0.62 & & Mmo08 & 1 & 0.00 & 0.00 \\
Mru04 & 5 & 0.32 & 0.43 & & Mmo10 & 2 & 0.00 & 0.23 \\
Mru05 & 2 & 0.00 & 0.15 & & Mmo11 & 2 & 0.17 & 0.16 \\
Mru06 & 4 & 0.13 & 0.16 & & Mmo15 & 2 & 0.43 & 0.48 \\
Mru09 & 4 & 0.08 & 0.49 & & Mmo19 & 8 & 0.60 & 0.80 \\
Mru10 & 3 & 0.26 & 0.57 & & Mmo20 & 2 & 0.00 & 0.23 \\
Mru11 & 4 & 0.21 & 0.54 & & Mmo21 & 5 & 0.27 & 0.64 \\
Mru12 & 3 & 0.00 & 0.63 & & Mmo22 & 6 & 0.45 & 0.81 \\
Mru14 & 2 & 0.00 & 0.32 & & Mmo24 & 2 & 0.09 & 0.08 \\
\hline Mean & 3.3 & 0.16 & 0.43 & & Mean & 3.3 & 0.22 & 0.38 \\
\hline
\end{tabular}

A: number of alleles. $\mathrm{H}_{\mathrm{o}}$ and $\mathrm{H}_{\mathrm{e}}$ : observed and expected Nei heterozygosity, respectively.

Table 3 - Diversity parameters estimated for Melipona rufiventris and $M$. mondury, using nine microsatellite primers designed specifically for $M$. bicolor.

\begin{tabular}{|c|c|c|c|c|c|c|}
\hline \multirow[t]{2}{*}{ Locus } & \multicolumn{2}{|c|}{ M. rufiventris } & \multicolumn{2}{|c|}{ M. mondury } & \multicolumn{2}{|c|}{ M. bicolor* } \\
\hline & A & $\mathrm{H}_{\mathrm{o}}$ & A & $\mathrm{H}_{\mathrm{o}}$ & A & $\mathrm{H}_{\mathrm{o}}$ \\
\hline Mbi32 & 1 & 0.00 & 1 & 0.00 & 4 & 0.63 \\
\hline Mbi215 & 1 & 0.00 & 1 & 0.00 & 3 & 0.50 \\
\hline Mbi218 & 4 & 0.28 & 4 & 0.09 & 3 & 0.12 \\
\hline Mbi232 & 2 & 0.00 & 3 & 0.09 & 4 & 0.88 \\
\hline Mbi233 & 1 & 0.00 & 5 & 0.43 & 6 & 0.88 \\
\hline Mbi254 & 3 & 0.48 & 4 & 0.57 & 3 & 0.38 \\
\hline Mbi256 & 1 & 0.00 & 1 & 0.00 & 4 & 0.50 \\
\hline Mbi259 & 1 & 0.00 & 1 & 0.00 & 2 & 0.12 \\
\hline Mbi278 & 1 & 0.00 & 1 & 0.00 & 5 & 0.86 \\
\hline Mean & 1.67 & 0.09 & 2.33 & 0.13 & 3.78 & 0.54 \\
\hline
\end{tabular}

*Peters et al. (1998). 
species-specific amplification, but when $M$. bicolor specific microsatellite primers were used, only three (Mbi218, Mbi232 and Mbi254) and four (Mbi218, Mbi232, Mbi233 and Mbi254) were polymorphic in $M$. mondury and $M$. rufiventris, respectively. It is interesting to note that the same loci were polymorphic in the two species, which can be explained through $M$. rufiventris and $M$. mondury being very close phylogenetically.

It was apparent that the mean number of alleles detected when using species-specific primers was much greater than with heterologous, and that heterozygosity in the two species almost doubled in comparison to that detected when employing primers designed for M. bicolor. However, in two heterologous loci (Mbi218 in $M$. rufiventris and Mbi254, in M. mondury and M. rufiventris), heterozygosity indices were higher than those observed in M. bicolor. Furthermore, in some loci $\mathrm{H}_{\mathrm{e}}$ and $\mathrm{H}_{\mathrm{o}}$ were discrepant. The segregation pattern of these loci was tested using ten workers from each colony and revealed that phenotypes were consistent with that expected for a haplodiploid system. This confirmed that the loci really represented genetic markers and that observed differences were possibly the result of sampling problems.

Low polymorphism levels and high numbers of monomorphic loci have already been detected in several studies of genetic diversity in stingless bees when using heterologous primers (Francisco et al., 2006; Borges, 2007; Silva, 2007; Tavares et al., 2007). For example, observed heterozygosity detected in populations of Partamona helleri, Plebeia remota (Francisco et al., 2006) and $M$. mondury (Tavares et al., 2007) was $0.11,0.24$ and 0.12 , respectively. This was much lower than what was detected in $M$. bicolor $\left(\mathrm{H}_{\mathrm{omean}}=0.40\right)$, the species for which the primers were originally designed.

This is mainly explained by the presence of null alleles that are not amplified because of mutations in the primer pairing sequence (Callen et al., 1993). In general, the number of alleles and genetic diversity are greater in species for which microsatellite primers were originally designed, and successful transferability is usually inversely proportional to mutual genetic distance (Primmer and Merilä, 2000). Carvalho-Zilse and Kerr (2006) observed this in $M$. scutellaris, where the success of transferability was greater with the use of primers specifically designed for $M$. bicolor, a species of the same genus, than with those for Apis mellifera. Similarly, Lopes (2008) observed that the transferability of primers designed for $M$. rufiventris and M. mondury was higher in other Melipona species than in Partamona helleri.

Another important mechanism to be considered when using heterologous primers is preferential amplification of one of the alleles during PCR, thereby possibly hindering detection of individual heterozygotes. In this case, the enzyme used in the process would be more active in amplifying the smaller sized allele, thereby generating an increase in the concentration of this in detriment to the larger one (Wattier et al., 1998).

From our data, it can be seen that, although heterologous primers can be successfully used in studies of phylogenetically close species, the results should be carefully analyzed, as the number of alleles and heterozygosity revealed in each case can vary, depending on various factors. Thus, the use of specific primers should be preferred in comparison to the heterologous. Nevertheless, it was shown that genetic diversity in the two Melipona species analyzed was low when compared to other bee species, even when using specific microsatellite primers (Peters et al., 1998; Paxton et al., 2003; Carvalho-Zilse and Kerr, 2006; Souza et al., 2007). For example, observed heterozygosity in M. scutellaris $\left(\mathrm{H}_{\mathrm{o}}=0.315\right.$ - Carvalho-Zilse and Kerr, 2006), was found to be higher than in M. rufiventris $\left(\mathrm{H}_{\mathrm{o}}=0.16\right)$ and $M$. mondury $\left(\mathrm{H}_{\mathrm{o}}=0.22\right)$ (present study). The low number of colonies found in several localities, as a consequence of habitat destruction and fragmentation, as well as predatory honey collecting, may be contributing to the reduction in genetic variability. In fact, in Minas Gerais, M. rufiventris and M.mondury consist of small local populations and these species have being so depleted, they are now considered endangered species (Campos, 1998).

\section{Acknowledgements}

The authors are grateful to the Brazilian agencies FAPEMIG (EDT 245/05) and CNPq, as well as to UFV for financial support, and to CAPES for supporting D.M. Lopes.

\section{References}

Callen DF, Thompson AD, Shen Y, Phillips HA, Richards RI, Mulley JC and Sutherland GR (1993) Incidence and origin of "null" alleles in the (AC)n microsatellites markers. Am J Hum Genet 52:922-927.

Campos LAO (1998) Melipona rufiventris Lepeletier, 1836. In: Machado ABM, Fonseca GAB, Machado RB, Aguiar LM and Lins LV (eds) Livro Vermelho das Espécies Ameaçadas de Extinção da Fauna de Minas Gerais. Fundação Biodiversitas, Belo Horizonte, pp 560-561.

Carvalho-Zilse GA and Kerr WE (2006) Utilização de marcadores microssatélites para estudos populacionais em Melipona scutellaris (Apidae, Meliponini). Magistra 18:213-220 (Abstract in English).

Estoup A, Solignac M, Harry M and Cornuet JM (1993) Characterization of (GT)n and (CT)n microsatellites in two insect species: Apis mellifera and Bombus terrestris. Nucleic Acids Res 21:1427-1431.

Ferreira ME and Grattapaglia D (1998) Introdução ao Uso de Marcadores Moleculares em Análise Genética. 2nd edition. Embrapa-Cenargen, Brasília, 220 pp.

Francisco FO, Brito RM and Arias MC (2006) Alelle number and heterozygosity for microsatellite loci in different stingless bee species (Hymenoptera, Apidae, Meliponini). Neotrop Entomol 35:638-643. 
Green CL, Franck P and Oldroyd BP (2001) Characterization of microsatellite loci for Trigona carbonaria, a stingless bee endemic to Australia. Mol Ecol Notes 1:89-92.

Hancock JM (1999) Microsatellites and other simple sequences: Genomic context and mutational mechanisms. In: Goldstein DB and Schlötterer C (eds) Microsatellites: Evolution and Applications. Oxford University Press, New York, pp 1-9.

Insuan S, Deowanish S, Klinbunga S, Suttipraneed S, Sylvester HA and Wongsiri S (2007) Genetic differentiation of the giant honey bee (Apis dorsata) in Thailand analyzed by mitochondrial genes and microsatellites. Biochem Genet 45:345-361.

Lopes DM, Silva FO, Salomão TMF, Campos LAO and Tavares MG (2009) Microsatellite loci for the stingless bee Melipona rufiventris (Hymenoptera, Apidae). Mol Ecol Res 9:923-925.

Paxton RJ, Arévalo E and Field J (2003) Microsatellite loci for the eusocial Lasioglossum malachurum and other sweet bees (Hymenoptera, Halictidae). Mol Ecol Notes 3:82-84.

Paxton RJ, Weißschuh N and Quezada-Euán JJG (1999) Characterization of dinucleotide microsatellite loci for stingless bees. Mol Ecol 8:690-692.

Pépin L, Amigues Y, Lépingle A, Berthier JL, Bensaid A and Vaiman D (1995) Sequence conservation of microsatellites between Bos taurus (cattle), Capra hircus (goat) and related species. Examples of use in parentage testing and phylogeny analysis. Heredity 74:53-61.

Peters JM, Queller DC, Imperatriz-Fonseca VL and Strassmann JE (1998) Microsatellite loci for stingless bees. Mol Ecol 7:783-792.

Primmer CR and Merila J (2000) A low rate of cross-species microsatellite amplification success in ranid frogs. Conserv Genet 3:445-449.

Souza RO, Cervini M, Del Lama MA and Paxton RJ (2007) Microsatellite loci for euglossine bees (Hymenoptera, Apidae). Mol Ecol Notes 1-5.

Tavares MG, Dias LAS, Borges AA, Lopes DM, Busse AHP, Costa RG, Fernandes-Salomão TM and Campos LAO (2007) Genetics divergence between population of the stingless bee uruçu amarela (Melipona rufiventris group, Hymenoptera, Meliponini): Is there a new Melipona species in the Brazilian state of Minas Gerais? Genet Mol Biol 30:667-675.

Waldschmidt AM, Salomão TMF, Barros EG and Campos LAO (1997) Extraction of genomic DNA from Melipona quadrifasciata (Hymenoptera, Apidae, Meliponinae). Braz J Genet 20:421-423.

Wattier R, Engel CR, Saumitou-LaPrade P and Valero M (1998) Short allele dominance as a source of heterozygote deficiency at microsatellite loci: Experimental evidence at the dinucleotide locus Gv1CT in Gracilaria gracilis (Rhodophyta). Mol Ecol 7:1569-1573.

\section{Internet Resources}

Borges AA (2007) Variabilidade genética de Partamona helleri Friese, 1900 (Hymenoptera, Apidae). Dissertação de Mestrado, Universidade Federal de Viçosa, 48 pp. http://www.tede.ufv.br/tedesimplificado/tde_busca/arquivo .php?codArquivo=896 (June 20, 2008).

Lopes DM (2008) Análises moleculares em Melipona rufiventris e Melipona mondury (Hymenoptera, Apidae). Tese de Doutorado, Universidade Federal de Viçosa. http://www.tede.ufv.br/tedesimplificado/tde_busca/arquivo .php? codArquivo=1576 (June 20, 2008).

Miller MP (1997) Tools for population genetic analyses (TFPGA) A Windows program for the analysis of allozyme and molecular population genetic data. http://www.marksgeneticsoftware.net/tfpga.htm (July 3, 2008).

Silva RR (2007) Variabilidade genética de Melipona quadrifasciata (Hymenoptera, Apidae, Meliponina). Dissertação de Mestrado, Universidade Federal de Viçosa, 41 pp, http://www.tede.ufv.br/tedesimplificado/tde_busca/arquivo .php? codArquivo $=896$ (June 20, 2008).

Yeh FC, Yang R and Boyle T (1999) Popgene version 1.32: Microsoft Windows-based freeware for population genetic analysis. University of Alberta, Edmonton, http://www.ualberta.ca/ fyeh/dowload.htm (July 3, 2008).

\section{Associate Editor: Louis Bernard Klaczko}

License information: This is an open-access article distributed under the terms of the Creative Commons Attribution License, which permits unrestricted use, distribution, and reproduction in any medium, provided the original work is properly cited. 